\title{
final years of the silver standard in mexico: evidence of purchasing power parity with the united states
}

\author{
Antonio N. Bojanic* \\ Professor of Economics / CENTRUM - Pontificia Universidad Católica del Perú \\ Urbanización - Los Alamos de Monterrico - Surco, Perú
}

\begin{abstract}
This paper focuses on the use of silver as a monetary standard in Mexico during approximately the last three decades of the nineteenth century and the first decade of the twentieth century. During this period, several events occurred in the market for silver that affected those countries attached to this metal. These events caused some of these countries to abandon silver for good and adopt other types of monetary arrangements. Mexico and a few others chose to stay with it. The reasons behind this decision are analyzed. Additionally, evidence that supports the theory of purchasing power parity between Mexico and the United States is also presented and analyzed.
\end{abstract}

KEY WORDS: Mexico, silver standard, theory of purchasing power parity

\section{RESUMO}

Este artigo enfoca o uso da prata como padrão monetário no México, durante aproximadamente as três últimas décadas do século XIX e primeira década do século XX. Durante esse período, vários eventos ocorreram no mercado de prata, que afetaram os países atrelados a este metal. Estes eventos causaram alguns destes países a abandonar a prata para o bem e adotar outros tipos de regime monetário. México e alguns outros, preferiu ficar com ele. As razões desta decisão são analisados. Além disso prova, que apoia a teoria da paridade do poder de compra entre o México e os Estados Unidos são também apresentados e analisados.

Palavras-chave: México, padrão prata, teoria da paridade do poder de compra

* The author wishes to thank Leland Yeager for helpful comments. The author alone is responsible for any errors that remain.Ph.1(703)475-7739<abojanic@pucp.edu.pe>. Submetido em maio 2011; aceito em julho, 2011. 


\section{Introduction}

In the 1870s, while most countries switched away from silver or bimetallism, Mexico and a few other nations remained on the silver standard. The reasons behind this decision are analyzed to determine what prompted these countries to stick with silver longer than most other nations. At the end of the day, the decision to stay with silver is found to be completely rational as some of these countries were producers of the metal, which justified clinging to it to support a significant domestic industry. Others simply enjoyed the benefits afforded by the continuous depreciation of silver ${ }^{1}$, which generated an artificial subsidy to their exports, produced a veiled protection to domestic industries competing with foreign goods, and might have also induced money illusion ${ }^{2}$ in certain groups of people. Mexico was both a traditional silver-producing nation and also experienced a significant export boom due, in part, to its adherence to silver, which made its products more competitive in the international markets. Mexico's remaining with silver longer than most other countries seems to have made perfect sense while the benefits of its currency attached to the metal outweighed the costs of such association.

The depreciation of silver, which helps explain Mexico's export boom between 1870 and the first decade of the new century, also had a significant impact on the economic relationship with the United States. As Kuntz (2000) demonstrates, in the 1870-79 decade, exports to the United States accounted for around 58 percent of total exports. In the next decades the share of exports to the US rose continually from 77 percent (in the 1880s) to 82 percent (in the 1990s). By the turn of the

1 India too remained with silver longer than most other countries, until 1893. In addition to having benefitted from the depreciating silver making its exports more competitive, this country was also a great consumer of the metal for cultural and historical reasons. As the Indian case illustrates, non-economic arguments also played a role in the decision to remain with silver.

2 Money illusion refers to a situation where people may have an illusory picture of their wealth and income based on nominal monetary terms rather than in real terms. A depreciating value of silver caused a depreciation of currencies attached to it. In those countries with currencies attached to silver, public servants and other economic agents receiving non-adjusted income or rents from government might have suffered from money illusion. 
new century, the share of exports to its neighbor to the north had increased to 83 percent and remained around this level well beyond 1910. In terms of imports, the share of US imports to total imports into Mexico rose from 25 percent in the 1870 s, to 46 percent in the 1880 s, 56 percent in the 1890s, and 64 percent in the 1900s. This ever-closer relationship with the United States is captured by purchasing-powerparity $^{3}$ estimations (PPP estimations) ${ }^{4}$.

Although some may argue that PPP estimations do not by themselves prove anything new, as the close economic association between the US and Mexico is well known and has been extensively documented, it is remarkable that no formal testing of this hypothesis exists in the literature ${ }^{5}$ for the period of interest. Most works on the subject of the economic closeness between US and Mexico seem to assume that PPP holds without actually testing for it. In this work, this theory is formally analyzed to determine whether purchasing power parity holds for two countries with a well established relation that exceeds economic considerations.

As stated earlier, this paper analyzes the silver standard in Mexico during approximately the final decades of the nineteenth century and first decade of the twentieth century. In order to build the proper context, Section 2 analyzes the silver standard in Mexico. It starts by analyzing the export industries that were most benefitted by the depreciation of silver. It points out the great increase in exports that the country enjoyed while its currency depreciated, and it analyzes how this export industry changed during Diaz's term as president. It also analyzes the evolution

3 The theory of Purchasing Power Parity states that exchange rates between currencies are in equilibrium when their purchasing power is the same in each of the two countries. The basis for PPP is the "law of one price": in the absence of transportation and other transaction costs, competitive markets will equalize the price of an identical good in two countries when the prices are expressed in the same currency.

4 While PPP is more likely to hold between trading partners, this is not necessarily always the case. Bojanic (2010) demonstrates that PPP held between Mexico and India during the latter part of the19th century and first years of the new century even though trade between these nations during that period of time is not known to have occurred. This author argues that these countries' common relationship with silver is what contributed to PPP holding between them.

5 As far as I can tell, only Gomez-Galvarriato and Musacchio (2000) come close, but not quite, as they only test for the existence of a long-run association between the exchange rate Peso $/ \$$ and three different Mexican price indices. 
of imports into the country, particularly as it refers to the role that capital inputs played in the industrialization of Mexico during the 1870-1910 period. Next, a brief account of Porfirio Diaz's government is provided with special emphasis on the political accomplishments and failures of his government during the thirty four years as president of Mexico. Finally, some of the opinions that surfaced around 1905 are reported, when Mexico was preparing to leave the silver standard for good, as well as a description of the internal economic situation that finally led to the deposition of Díaz in 1911.

Section 3 presents purchasing-power-parity calculations between Mexico and the United States for the period 1886-1913. Other comparisons, such as differences in price fluctuations and the depreciation of the Mexican peso in step with silver, are also reported and analyzed. The results obtained are presented as evidence of the existence of purchasing power parity between the two countries. The calculations were done through the Ordinary Least Squares (OLS) Method, Cointegration Analysis, and with the help of graphs. As enunciated earlier, the importance and relevance of finding that PPP held with the United States rests on the fact that even back in the nineteenth century, Mexico's main trading and economic partner was its neighbor to the North. The US was Mexico's main export market and it was also the country's most important provider of industrial inputs. The fall in the price of silver - and hence on the value of the peso - deepened the dependency with the United States. The export boom that began in the 1890 s and that was triggered by the depreciation of the peso was principally directed to the US market. Likewise, the rapid industrialization of the Mexican economy that occurred during the same period took place mainly with industrial inputs and technical assistance from the US. The formal testing of the existence of PPP between these two countries for the period 1886-1913 confirms the historically deep ties that have united these two countries for so long.

Section 4 presents a summary of the most important findings of this work. 


\section{The Silver Standard in Mexico}

A silver standard can be defined as a monetary standard under which the basic unit of currency is equal in value to and exchangeable for a specified amount of silver ${ }^{6}$. This standard was the prevalent monetary arrangement around the world for most of the nineteenth century. Silver, along with gold in the second half of the same century, were the two metals of choice for countries on a metal-backed standard. The ratio between the value of equal weights of silver and gold, which had been about 11 to 1 before the discovery of the Americas, when new discoveries of these metals occurred, rose gradually to about 15.5 to 1 , where it remained until the latter part of that century. Since silver and gold were the metals of choice for countries with a metal standard, there were many attempts to establish a fixed value ratio between them for coinage purposes. Some authors argue that these attempts were never truly successful (LEAVENS, 1939), while more recently others have suggested that attempts at establishing a fixed value between the two metals were indeed successful for a long time, and that the demise of silver-backed standards was not a foregone conclusion (FLANDREAU, 2004).

Mexico was theoretically on a bimetallic standard since early in the sixteenth century with a coinage ratio of approximately 16 to 1 between silver and gold. Little gold was ever coined and none ever circulated, so Mexico was practically on a monometallic standard. Before the expansion of silver production in the United States in the 1870s, Mexico was the world's largest producer of the metal. After 1870, the United States and Mexico were its two leading producers, so it is not surprising that the fall in the price of silver from 1873 to around 1910 profoundly affected the Mexican economy.

Before 1870, the market ratio between silver and gold fluctuated between 15.5 and 16 to 1 worldwide. The 16 to 1 coinage ratio was equivalent to a bullion parity, or US monetary value of silver, of $\$ 1.29$ per ounce. The bimetallism of France and other major European countries, as well as the monometallic standard of Germany, kept the

6 This definition was adopted from the Gold Standard definition found in The American Heritage Dictionary of the English Language. The world "gold" was replaced in the text with the word silver. 
silver/gold ratio and thus the exchange rates of silver-standard countries fairly stable; no exchange-rate problem was giving the silver countries a reason to switch standards. Mexico was quite comfortable with its silver standard and felt untouched by the seemingly harmless mild fluctuations of the silver-to-gold price ratio on the world market.

This situation changed shortly after 1870 , as new forces affected the silver market. World silver production increased from about 25 million ounces in the 1840s to about 160 million in the 1890s (MITCHELL, 1992). This increase in silver production was compounded in 1873 when Germany abandoned the silver standard and adopted the gold standard. Germany's dumping of silver in the world markets after 1873 exerted even greater pressure on the price of silver, and during the 1870s it became evident that the old coinage ratio or bullion parity between the two metals was untenable. Like the rest of the world, Mexico began feeling the effects of silver's depreciation during the 1870s.

This depreciation had great repercussions on the Mexican economy, especially since Mexico stuck to silver throughout the 1870s and well into the first decade of the twentieth century. As is often true in countries with devalued currencies, Mexico's export trade was greatly stimulated, as were domestic industries producing substitutes for previously imported goods. The degree to which export industries were helped by a growing foreign demand for Mexican products and the ability of importsubstituting industries to satisfy domestic demand are, of course, issues crucial to understanding the real effects that the depreciation of silver had in Mexico.

The first part of this section focuses on Mexico's foreign trade over roughly the period 1873 to around 1910 . The second part analyzes the political climate and the role that Porfirio Díaz played during his 33-year term (1877-1911) as president of Mexico, with a brief interlude in the mid 1880s, when Díaz did not preside over the government. The final section analyzes Mexico's internal economic situation and its possible connection to the revolution that finally deposed Díaz in 1911.

\section{Foreign Trade}

As stated earlier, until 1873 the price of silver was almost always above $\$ 1.29$ + per ounce, corresponding to the US coinage ratio of 16 
to 1 between silver and gold. After 1873, the price of the metal declined for 20 years, until 1893, although in 1890, with passage of the Sherman $\mathrm{Act}^{7}$ in the United States, the price of silver rose for a brief period of time. Then it fluctuated around 60 cents per ounce, corresponding to a ratio of about 34 to 1 . The depreciation of silver translated into a devaluation of the Mexican peso, which remained on the silver standard until 1905. Between 1873 and 1911 the price of the peso in New York fell from $\$ 1$ to 49.8 cents. During the 1890 s alone the peso sank 37 percent against the dollar, from 75 to 47 cents. From 1900 until 1903 the peso fluctuated around 47 cents, then falling to 40 cents, its lowest price until then. Adoption of the gold standard in 1905 stabilized the peso at 50 cents, a rate that changed little for the remainder of the period of interest (GOMEZ-GALVARRIATO, 1999).

This brief history of the peso's dollar value is important. Exchange rate fluctuations closely mirrored fluctuations in the price of silver. Furthermore, the continuing depreciation of silver and the peso, particularly before 1900, contributed to the great expansion of Mexico's export industries by making Mexican products cheaper to foreign buyers. The depreciation in effect subsidized Mexican exports, since it outran any rise in Mexican prices and costs. Table 1 below reports disaggregated export figures for two points in time, $1877-78$ and $191-11^{8}$.

7 The Sherman Act of 1890 required the US Secretary of the Treasury to purchase monthly 4,500,000 ounces of silver at the market price to be paid for by the issue of treasury notes. In August 1893, the silver-purchase clauses of the Sherman Act of 1890 were repealed. It is widely believed that the Act was enacted in order to boost the price of silver.

8 Source for figures in tables 1 and 2 is Estadísticas Económicas del Porfiriato. 1. Comercio Exterior de México, 1877-1911, El Colegio de México (1960). Even though these trade figures have been updated and improved by the work of Sandra Kuntz $(2000,2002$, 2007, 2010), they are still quoted to emphasize general tendencies in the behavior of different groups of products. More detailed analysis of export and import trends is presented in Table 3, where the new trade series - constructed by Kuntz - are utilized. 
Table 1 - Mexican Exports in 1877-78 and in 1910 -11

\begin{tabular}{l|c|r|r|c}
\hline & \multicolumn{2}{|c|}{$1877-78$} & \multicolumn{2}{c}{$1910-11$} \\
\hline & Value & $\%$ & Value & $\%$ \\
\hline Precious Metals & 12.57 & 65.02 & 69.38 & 50.64 \\
\hline Industrial Metals & 0.05 & 0.25 & 17.62 & 12.86 \\
\hline Agricultural Products & 6.14 & 31.77 & 48.76 & 35.59 \\
\hline Other Products & 0.57 & 2.96 & 1.24 & 0.90 \\
\hline TOTAL & 19.33 & 100.00 & 137.00 & 100.00 \\
\hline
\end{tabular}

Notes: Fiscal year beginning in July 1 and ending in June 30 of the following year All figures above are in nominal million of dollars, base year $=1900-01$

Source: Estadísticas Económicas del Porfiriato: Comercio Exterior de México, 1877-1911, El Colegio de México

As can be observed, the greatest increase i n exports occurred with industrial metals (copper and lead), which accounted for about 13 percent of the total value of exports at the end of the fiscal year 191011, up from a meager 0.25 percent in $1877^{9}$. The share of agricultural products did not change much over this period, but their composition did: sisal hemp and rubber gained at the expense of more traditional agricultural products like precious woods. The share of other products, like cattle and coffee, fell two percentage points. The share of precious metals shrank considerably, although gold and silver remained the country's two most important export goods.

Export expansion was triggered by the depreciation of silver, which made Mexican products cheaper in foreign markets as long as domestic prices and costs did not rise fully in step with the depreciating peso. This contribution to a favorable trade balance was offset by increased imports of capital goods for domestic industries. The latest production technologies were introduced, particularly in mining but also in other industries. In 1884, capital investment did not reach 57 million 1900-01 dollars. By 1911 this figure had climbed to 1,619 million dollars, or around 29 times the capital investment of 1884 (BEATTY 2000). Increased exports and capital investment and their side effects, such as urbanization and industrialization, caused the import sector economy

9 Kuntz (2007) shows that these industrial metals were mainly absorbed by the US and were utilized in this country's process of industrialization, particularly in the vast expansion of urban centers throughout the nation. 
to expand also.As Table 2 shows, imports expanded considerably, although not as much as exports.

Table 2 - Mexican Imports in 1888-89 and in 1910-11

\begin{tabular}{l|r|r|r|c}
\hline & \multicolumn{2}{|c|}{$1888-89$} & \multicolumn{2}{c}{$1910-11$} \\
\hline & Value & \multicolumn{1}{c|}{$\%$} & \multicolumn{1}{c}{ Value } & $\%$ \\
\hline Consumption Goods & 19.33 & 52.80 & 43.76 & 43.04 \\
\hline perishable/unprocessed & 0.90 & 2.47 & 7.81 & 7.68 \\
\hline perishable/processed & 14.62 & 39.92 & 23.52 & 23.14 \\
\hline not perishable & 3.81 & 10.40 & 12.43 & 12.22 \\
\hline Production Goods & 17.29 & 47.20 & 57.90 & 56.96 \\
\hline unprocessed inputs & 3.14 & 8.58 & 5.86 & 5.76 \\
\hline processed inputs & 6.10 & 16.64 & 21.62 & 21.26 \\
\hline capital goods & 8.05 & 21.98 & 30.43 & 29.93 \\
\hline TOTAL & 36.62 & 100.00 & 101.67 & 100.00 \\
\hline
\end{tabular}

Notes: Fiscal year beginning in July 1 and ending in June 30 of the following year All figures above are in nominal million of dollars, base year $=1900-01$

Source: Estadísticas Económicas del Porfiriato: Comercio Exterior de México, 1877-1911, El Colegio de México

The distribution of imports changed considerably. The share of production goods rose from 47.2 percent in 1888-89 to almost 57 percent in 1910-11. The decrease in the share of consumption goods from about 53 to 43 percent suggests that Mexico's import-substituting industries made great progress over the period as the prices of foreign goods rose due to a depreciating Mexican currency.

The decline in the share of consumption goods was mostly concentrated in perishable/processed goods - food, tobacco, clothing, and the like - as domestic industries producing similar goods developed. Nonperishable goods like jewelry were mostly bought by the higher economic classes: their share of total import value rose as Mexico became more prosperous. Perishable/unprocessed goods, or basic grains, also gained in import share as their domestic production lagged.

The growth in imports of production goods accompanied the flourishing of import-substituting industries. Unprocessed inputs, like cotton, declined in import share as their domestic production grew. Processed inputs, like nails, were imported for use in the public works 
and railroad expansion that were so extensive during Diaz's administration. Furthermore, many of the companies, private and public, acquired machines and tools not available domestically. Imports of these capital goods rose quite considerably, their share rising from 22 percent of total imports in 1888-89 to around 30 percent in 1910-11. Williamson and Gomez-Galvarriato (2008) report that on a decade-by-decade basis between the years 1870 and 1900, Mexico's imports of manufacturing capital imports grew at a faster rate than in other emerging Latin American nations (Argentina, Brazil and Chile), which confirms the comparatively more rapid industrialization that took place in Mexico during those years. This pattern in the behavior of capital imports was reversed during the period 1901-1911, as Mexico's economic growth slowed down and the country prepared itself to adopt the gold standard.

A more detailed analysis of trade figures offers revealing patterns for the period under consideration. Table 3 below reports balances of trade in merchandises and in metals for each of the decades analyzed in this work ${ }^{10}$.

Table 3 - Balance of Trade by Decades, 1870-1910

\begin{tabular}{c|c|c|c|c}
\hline Decade & $\begin{array}{c}\text { Exports of } \\
\text { Merchandises }\end{array}$ & $\begin{array}{c}\text { Imports of } \\
\text { Merchandises }\end{array}$ & $\begin{array}{c}\text { Balance of Trade } \\
\text { in Merchandises }\end{array}$ & $\begin{array}{c}\text { Balance of trade } \\
\text { in metals }\end{array}$ \\
\hline $1870-79$ & 95,80 & 233,00 & $-137,20$ & 213,40 \\
\hline $1880-89$ & 179,30 & 357,00 & $-177,70$ & 250,70 \\
\hline $1890-99$ & 425,00 & 485,30 & $-60,30$ & 211,10 \\
\hline $1900-10$ & $1.000,20$ & $1.053,70$ & $-53,50$ & 208,60 \\
\hline
\end{tabular}

Notes: Figures are nominal values and reflect millions of dollars Source: Kuntz (2002)

As can be observed, the growth of merchandise exports between the 1870s and the first decade of the 1900s is immense: over 940 percent.

10 Table 3 utilizes the latest and most updated trade figures estimated in Kuntz (2002) paper. In addition to providing consistent estimates by comparing official statistics of Mexico and its main trading partners, Kuntz differentiates between commodity trade and specie movements, hence avoiding the problems of trade figures in other sources which group exports of metals without making a distinction between valid exports of minerals and specie payments - particularly in silver metal - for imports and other obligations. 
As stated earlier, this growth in exports is unsurprising due to a depreciating currency moving in tandem with a depreciating silver metal. It outpaces the growth in imports for the same period (over 350 percent) by almost a factor of three. The 1880s and the first decade of the new century record the greatest growth in exports (104 and 118 percent, respectively). The growth in imports is also greatest in those decades (77 percent in the 1880s and 57 percent in the 1900s), but at a significantly lower rates. In the four decades between 1870 and 1910 , Mexico experienced continuous trade deficits that were financed by consistent surpluses of trade in metals and, as described by Márquez (2001) and Beatty (2000), by inflows of different types of foreign capital attracted by Mexico's rapid industrialization process.

It is interesting to note that despite Mexico's substantial economic progress - reflected in its growing capacity to export a more diversified set of products - lingering social problems persisted, and as the new century arrived, these issues became more evident. The 1900s were not as kind to Mexico as the previous twenty years. Economic growth slowed down for several reasons. For one thing, the Mexican peso did not continue depreciating, stimulating exports, as it had done in the 1890s. Its value hovered around 47 US cents for the first couple of years, and then reached its lowest level ever, 40 cents, in 1903. In 1905 Mexico switched to a gold standard. This switch, instead of helping to alleviate the economic slowdown, contributed to the country's problems in two ways. It caused rising internal prices for Mexican consumers, since these prices started catching up with the exchange depreciation of the silver peso, and the export industry was no longer subsidized by its currency being pegged to the value of a depreciating metal. Rising internal prices, a declining export industry, low domestic production of goods, and a general unhappiness among the populace, made the eventual transition to a new government inevitable. That is what the revolution of 1910 finally accomplished.

\section{Political climate under Porfirio Díaz}

Throughout most of the eighteenth century, Mexico, like most countries in Latin America, was a fairly rudimentary economy. Detailed figures on growth of the economy, goods produced within the country, 
wages, foreign trade figures and the like, are at best scattered. It is a fairly accepted fact, though, that the growth of the Mexican economy at the beginning of the eighteenth century was quite low. Foreign trade was almost completely concentrated on two countries, the United States and England, although other European countries had invested money in the country, some of it in the form of loans to the Mexican government. Following 1867 the country's relations with other countries began to take on a new modern look. Mexico finally began to enjoy prosperity against a background of domestic peace. The government of Benito Juarez (1858-1872) is widely believed to have helped the formation of a stronger national government and a stronger awareness of the necessity to engage in trading relationships with a larger spectrum of countries. Juarez's main concern was education, which he saw as the most important way to achieve true economic development. By the time Porfirio Díaz came to power in 1877, Mexico was well on its way to dismantling the feudal social, political, and economic system that had characterized his country for so long, though traces of such a system still exist today, as Haber (1995) ably illustrates on his work on Mexico's industrialization process during the 1890-1940 period.

Díaz then took over a country that had already started a revolution of its own. His administration continued this revolution by further modernizing the country with public works, notably the construction of railroads, hospitals, and schools; and it began attracting foreign capital into Mexican export industries. Furthermore, Díaz eliminated the internal trade barriers that had inhibited the free flow of goods and services among the country's different states. Thus, even though the dictatorship of Díaz ended abruptly in 1911, it is undeniable that his government pursued policies that paved the way for Mexico to become a modern and relatively prosperous country, at least during part of his time in office.

Even though great progress was made in several areas under Diaz's rule, it did not extend to making the great masses of the people better off. Rather, economic differences between rich and poor widened, and this lack of progress among the great majority of people proved costly as the first decade of the twentieth century came to an end. Riguzzi (2009), in a lucid analysis of the political economy of the Diaz administration, assesses the arguments that link features of Porfirian 
economic organization with the outbreak of the Mexican revolution in $1910^{11}$.

The dictatorship of Porfirio Díaz subdivides into three periods: "Porfirismo", "Porfiriato", and "Porfiriazo". Porfirismo lasted from 1877, when Díaz seized power, until about 1891. Promising change for the better, Díaz enjoyed mass appeal in this first period. Most parts of the country saw great development. The railroads were expanded to connect the main seaports, Veracruz and Tampico, with internal centers of production, especially of agricultural goods. Cities along the US border were connected to Mexico City, benefitting intervening localities with new markets for their products. This period also brought unusual peace to a country where populist revolts had been the norm rather than the exception. One suggested reason for this lack of internal conflict is that Díaz restored religious liberty, previously much restricted.

The second period, the "Porfiriato", running from about 1891 to 1904, was the one of greatest economic progress. It was also, coincidentally and key to the arguments of this paper, the period when the price of silver reached its lowest level. The country's export industries really took off, and infrastructure, railways in particular, developed more than ever. The export industries, traditionally dominated by gold, silver, and other mining products, expanded to include goods like coffee, sisal hemp, copper, and varieties of precious wood ${ }^{12}$. The provision of essential services to the people lagged, however, while property rights and other institutions evolved in a way that, according to some authors (SCHETTINO, 2007), may have widened differences between rich and poor $^{13}$.

11 In a closely related article, Musacchio, et al. (2008) show the negative impact of the Mexican revolution during the 1920s. Net company startups, in terms of capital, decreased as a result of the armed conflict, and never returned to the levels of the Porfirio Díaz era.

12 Passananti (2007) argues that during the early Porfiriato years Mexican officials deftly negotiated the pace and sequencing of the country's reinsertion in the world economy. The government's ability to exploit significant capital flows without undermining domestic support, helps explain the regime's early economic growth and political resilience.

13 Catao (1998) argues that contrary to popular belief, Mexico's unprecedented growth in exports during the 1877-1910 period, had little impact on key ma- 
The "Porfiriazo", lasting from about 1904 to 1911, brought disenchantment among the masses that had first supported Díaz. Economic growth slowed, export industries stagnated, and a world financial crisis hit a vulnerable Mexico. During this first decade of the twentieth century, specifically in 1905, Mexico switched from silver to a gold standard to limit fluctuations of the peso's exchange rate. The export industry, which had been subsidized by depreciation of the silver peso, was hit hard, as was the general population, which now had to cope with internal prices rising both in lagged consequence of silver's earlier depreciation and in consequence of linkage to gold currencies now declining in purchasing power.

In 1905 , for the first time in several decades, the Mexican peso acquired a fixed exchange rate against the US dollar. In that year, also, the country began experiencing rising internal prices, a weakening of internal markets, and withdrawal of the subsidy to exports previously conferred by a depreciating silver peso. Such realities affected the government of Porfirio Díaz adversely in many ways, and in 1910 Mexico reverted to revolution. The masses that had once supported Díaz sent him into exile the following year $^{14}$. Schell (1996), in addition to analyzing the influence of silver on the economic cycles during the Porfiriato, examines the impact of Mexico's conversion to gold in 1905 and its subsequent contribution to the economic recession that preceded the revolution of 1910. Kemmerer (1940), in turn, offers a comprehensive analysis of the consequences of the revolution that finally deposed Díaz, with special emphasis on the monetary chaos generated during the 1912-1917 period.

Interestingly, most textbooks and commentators refer to the 33 years of Diaz's dictatorship as the "Porfiriato". They seem to associate him with the period of greatest progress during his presidency.They tend to forget the earlier and latter periods of Porfirismo and Porfiriazo. During the earlier one, the country was emerging onto the international scene with growing exports and a promising internal economy. During the

croeconomic and sectoral indicators, giving credence to the opinions of authors like Schettino.

14 Even though most authors argue that the crisis that finally deposed Díaz from power was mainly political, it can sensibly be argued that the economic hardships endured by most Mexicans due to the adoption of the gold standard played an even greater role in making the Díaz dictatorship untenable. 
latter, Mexico reverted to the social, economic, and political backwardness that had characterized it for so long.

\section{Internal Economic Conditions}

The foreign sector had great impact on the internal workings of the Mexican economy. Prosperity in trade with other countries furthered the development of a market system at home. Regulations restricting the flow of goods inside Mexico were abolished, and various investments enhanced the productive sector. Railroad expansion was of special significance for domestic industries. Rail links helped trade among localities to flourish. Rail tracks grew from just a few hundred kilometers in the early 1880s to around 20,000 kilometers in 1911 (COELLO et al. 1965).

Certain industries enjoyed dramatic development. The mining sector was the most dynamic. Production grew at about seven percent a year between 1877 and 1911. This growth was the direct result of foreign demand for Mexican metals, particularly silver and gold, but production of industrial metals like copper and lead also became quite important. Import-substituting industries flourished, growing at about five percent a year between 1877 and 1907. Most of the growth was concentrated in firms producing food and clothing, but firms producing chemicals and construction materials also benefitted. Agricultural production also grew, although technology did not advance much, high-intensity manual labor remaining the most important input in agriculture.

Of particular interest is the development of monetary instruments. Maurer (2002) details an interesting and provocative history of the banking system in Mexico, with special emphasis on the Porfirian economy and the necessary and mostly positive role that banks played in furthering the development of the economy during the Diaz's administration. Among other things, he describes how the banking system was developed to meet the growing needs of domestic and foreign trade. In a related work, Ludlow and Marichal (1986) delineate the development of the banking sector in the country during the Porfirian years, emphasizing the relationship between economic and political influence. At any rate, the development of this industry was substantial during the period under consideration: in 1877 the medium of exchange 
was composed solely of metallic coins. In 1880, with barter sill widely used throughout the country, coins in circulation barely surpassed 25 million pesos, hardly enough to support the level of trade that the country would reach in later years. The growth in foreign trade and the advances in domestic markets forced Mexico to develop other instruments. At the beginning of the 1880s banknotes appeared, and by the 1890s banks were offering saving deposits to customers. By 1910, the amount of medium of exchange reached 310 million pesos, of which 38 percent was coins, another 38 percent banknotes, and the rest deposits at private and public banks. Table 4 gives a breakdown of types of medium of exchange at five different dates.

Table 4 - Percentage Composition of the Medium of Exchange

\begin{tabular}{c|c|c|c|c}
\hline Years & $\begin{array}{c}\text { Circulating } \\
\text { Metal Coins }\end{array}$ & $\begin{array}{c}\text { Circulating } \\
\text { Currency } \\
\text { Notes }\end{array}$ & Deposits & Total \\
\hline $1877-78$ & 100.00 & 0.00 & 0.00 & 100.00 \\
\hline $1881-82$ & 94.30 & 5.70 & 0.00 & 100.00 \\
\hline $1894-95$ & 65.60 & 34.30 & 0.10 & 100.00 \\
\hline $1900-01$ & 46.20 & 45.60 & 8.20 & 100.00 \\
\hline $1910-11$ & 38.00 & 37.60 & 24.40 & 100.00 \\
\hline
\end{tabular}

Notes: Fiscal year beginning in July 1 and ending in June 30 of the following year

Source: Estadísticas Económicas del Porfiriato: Comercio Exterior de México, 1877-1911, El Colegio de México.

A final aspect of the Mexican economy worth analyzing is capital formation. Due to scarcity of domestic resources for meeting internal and export demands, Mexico, and more specifically the Díaz government, sought foreign capital goods for use in all productive areas. The industries that most benefitted from these capital goods were clearly those having most to offer foreign customers, so it comes as no surprise that the mining industry received the largest infusion of foreign capital goods.

Foreign capital helped Mexico in other important areas, as in the expansion of railroads and the development of electricity for public and private use. Most of the foreign capital came from the United States, especially after 1890 , and from Great Britain. These two countries were Mexico's main trading partners and so had a direct interest in the country's economic development. Foreign capital also diversified into 
many other sectors. It helped Mexico set up its banking system and, interestingly enough, helped finance the country's public debt at various times. Even back in those days, Mexico's internal markets were obviously luring the attention of foreign investors. One can only wonder what would have happened if the revolution of 1910 had never taken place and Porfirio Díaz had remained in power for another ten years. Perhaps the economic revolution that he started would then have yielded the results that most Mexicans wanted but apparently never received during the Porfiriato.

A topic of interest to economists and historians is the economic and political debates that took place in the country as it prepared to switch to a gold standard. In 1903, an editorial in The New York Times ${ }^{15}$ quoted the Mexican minister of Finance, JoséYves Limantour, defending Mexico's silver standard and denying that Mexico was readying itself to abandon it in favor of gold. As the year 1905 approached, however, there were many different opinions about what the Mexican currency should be. Some people favored the silver standard and wanted their currency to stay attached to the fluctuations in the price of this metal. Not surprisingly, those who wanted to stick with silver were those who had been favored by its depreciating value. Exporters and silver producers, who had directly benefitted from a devalued peso, were the most fervent supporters of a continued silver standard in the country. On the other hand, those groups that were importing goods were negatively affected by the higher prices paid for these goods and so were in favor of switching to a gold standard, which would stabilize fluctuations in the peso exchange rate. The government of Mexico was divided: on the one hand, its foreign debt and dividends to foreigners investing in the country had to be paid in gold prices, and so these payments had increased dramatically due to the depreciating peso. On the other hand, its export industry, and hence its export revenues, had greatly increased during this period thanks to the peso devaluation, which caused some people in the government to be in favor of staying with silver. This latter point of view is clearly reflected in the opinions of Matías

15 New York Times, May 11, 1903. 
Romero, a government official during the Porfiriato: 'Even though we have suffered the inconveniences of a silver standard, we are satisfied with it since its benefits greatly outweigh the costs we have had to pay' (VILLEGAS, 1955). Those in favor of staying with silver based their argument solely on the fact that it was subsidizing Mexico's export industry. Those opposed to silver were mostly concerned with the increase in Mexico's foreign debt payments and the dividends the country had to pay to foreign investors. Barrera Lavalle, another government official, exposed the view of those opposed to the silver standard in these words: 'Our balance of payments (in 1900-01) has a deficit of 13 million pesos due to increased payments on our foreign debt and increased payments of dividends to foreigners' (VILLEGAS, 1955). He was one of the advocates of the gold standard and thought that a favorable balance of trade did not completely offset the increased payments that had to be made thanks to a depreciated peso.

At any rate, in 1905 Mexico switched to a gold standard and joined the community of gold-standard countries. This switch had its predicted effects: the export industry was no longer subsidized by a depreciating currency, and payments to foreigners were finally quoted in terms of the metal to which the Mexican currency was pegged. In defending Mexico's switching to gold, Limantour - the same finance minister who two years earlier had denied any possibility of adopting the gold standard - in 1905 stated: 'the silver standard helped only the export industry of the country. Its development though, never extended to other sectors of the economy; this made switching to a gold standard necessary' ${ }^{\prime 6}$.

\footnotetext{
16 Musacchio (2002) demonstrates that the decision to switch to gold was made before the creation of the Mexican Monetary Commission in 1903. He argues that the role of this Commission was not to consider the possibility of a switch to gold but rather to decide the best ways to adopt the gold standard.
} 


\section{Graphical Analysis and Purchasing Power Parity Estimations ${ }^{17}$}

It has been noted that after 1870 the price of silver depreciated greatly in world markets, from a high of 60.56 pence per ounce 0.925 fine in 1870 , to a low of 24.06 pence in 1902 . This decline in the value of silver was most evident after 1890, but its depreciation occurred throughout most of this 40-year period from 1870 to 1910 .

The depreciation in the price of silver was due to a number of reasons. As was discussed previously, during the 1870s many industrialized countries, most notably Germany in 1873 , closed their mints to silver and switched to some form of gold-backed currency. The United States omitted the silver dollar from the Coinage Act of 1873, which paved the way for the gold standard because it left the privilege of free coinage to gold but took it away from silver. The US remained on its Civil War paper basis until specie payments resumed in 1879. The departure of countries like Germany and the US from the silver standard, along with other factors that had been previously analyzed, caused a continuous decline in the value of silver that lasted until 1890, when the Sherman Silver Purchase Act was enacted in the United States. This Act enabled the US Treasury to buy silver in the world markets to counteract the decline in the value of the metal, a decline that was having negative effects on certain sectors of the US economy, particularly the agricultural and silver-mining industries.

As can be observed in Figure 1, with the exception of the year 1890, when the value of an ounce of silver went up to 47.75 pence from a previous low of 42.69 pence in 1889 , silver depreciated continuously, with the most acute depreciation taking place in the 1890s, when several international commissions ${ }^{18}$ established to deal with the world silver

17 The Mexican Price index was taken from Gomez-Galvarriato \& Musacchio, A. (2000). The exchange rate Pesos/\$ was also taken from this article. The reader is advised to refer to this article for further information on the sources of the exchange rate. The US price index was taken from Warren \& Pearson (1933).

18 Summaries of the conclusions from different appointed commissions established to deal with the silver question are found in the Royal Commission on Indian Currency and Finance, Vol. 1, 1926. 
question failed to reach any credible agreements as to what should be done with respect to silver.

Figure 1 - Price of Silver and Exchange Rate \$/Peso, 1870-1909

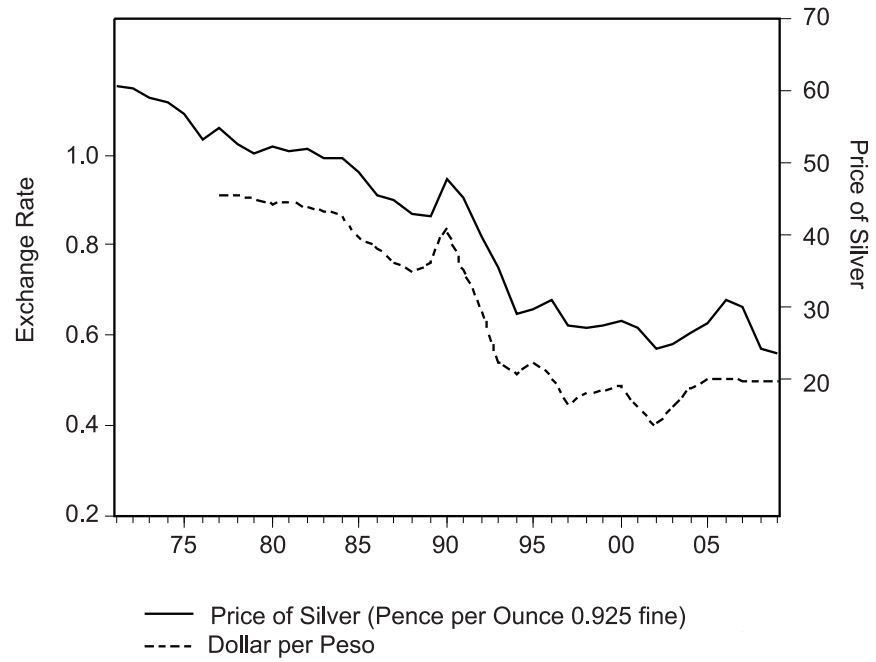

The departure of India from the silver standard in 1893 and the repeal of the Sherman Act the same year only made the decline in the value of silver more evident. After 1894 silver continued to depreciate, but at a slower rate, reaching a new level of 28.31 pence in 1900; thereafter it fluctuated in value until, in 1910, its price was 24.66 pence per ounce.

Mexico was on a silver standard throughout this period until it adopted the gold standard in 1905. As would be expected, the decline in the value of silver caused a depreciation of its currency. Since the United States finally went back to a gold standard in 1879 from its previously inconvertible greenback currency, its currency with respect to the Mexican currency appreciated in value after this year, and as can be observed in Figure 1, the dollar-per-peso exchange rate path followed a path very much like the one for the price of silver.

Like the price of silver, the depreciation of the peso after 1877 proceeded gradually until 1890, when the Sherman Act was enacted in the US. In 1877, the average dollar-per-peso rate was 0.919 , but by 1889 it had gone down to 0.758 . With the help of the Sherman Act the 
exchange went back to 0.837 in 1890 , but in 1891 it went back down to 0.743 . The depreciation in the exchange rate then accelerated until 1893, when India went off the silver standard and the Sherman Act was repealed. From then on, the peso depreciated more slowly. The rate was at 0.488 in 1900 and oscillated around this level until 1905, when Mexico finally adopted the gold standard and acquired a fixed exchange with the US dollar. In Figure 1, the year 1905 is the point at which the dollar-per-peso rate levels off and maintains itself constant until the end of the period of interest.

The basic differences between Mexico and the United States are apparent. While one, the United States, adopted the gold standard in 1879, the other, Mexico, remained on the silver standard until 1905. Mexico's currency depreciated greatly over this period, and this depreciation reflected wider fluctuations in the price level of the country. Figure 2 compares the price indexes for Mexico and the United States for the period 1886-1913.

Figure 2 - Price Indexes for Mexico and the US, 1886-1913

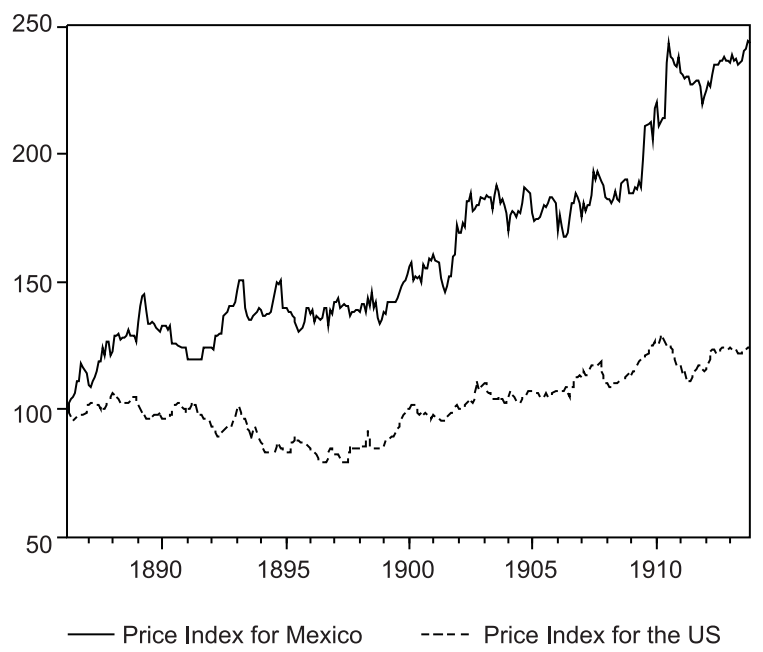

The price indexes in Figure 2 were converted to a common base month, March 1986. As indicated earlier, the price index of Mexico fluctuates substantially while the one for the United States shows a gradual decline until 1896, but thereafter it bounces back and a gradual 
upward trend is observed for the rest of the period. What is noteworthy about Figure 2 is that after 1905 the price level in Mexico increased even more than before this year, when it adopted the gold standard.This development was due to the fact that by this time prices were increasing in gold-standard countries throughout the world, and Mexico, by switching to this standard, felt the same effects on its price level as did countries already on gold.

Purchasing Power Parity (PPP) calculations between Mexico and the United States for the period March 1886 through October 1913 were done through the OLS method and cointegration analysis. Vector error correction estimates are also presented with the cointegration results.

The Mexican price index is a consumer price index and was constructed on the basis of 1930 prices; the basket of goods utilized to construct the price index was obtained through surveys made to workers of the Mexican Treasury Department and represent the most sophisticated work done in the area up until that time. The US price index is also a consumer index. The base month for both indexes were converted to March 1886, the beginning of the time series utilized here. The base month for the exchange rate Pesos $/ \$$ and the price ratio between the Mexican Index and the US Index were also converted to March 1886.

Ordinary Least Squares (OLS) purchasing power parity (PPP) calculations between Mexico and the United States for the period March 1886 - October 1913 are presented in Table 5.

Table 5 - OLS Regressions for the Peso/\$ Exchange Rate and $\log (\mathrm{Peso} / \$)$ Exchange Rate, 1886-1913

\begin{tabular}{l|c|c|c|c}
\hline & On $\mathrm{P}^{\star} \mathrm{P}^{\star}$ & On $\mathrm{P}, \mathrm{P}^{\star}$ & $\begin{array}{c}\text { On } \log (\mathrm{P} / \\
\left.\mathrm{P}^{\star}\right)\end{array}$ & $\begin{array}{c}\text { On } \log \mathrm{P}, \\
\log \mathrm{P}^{\star}\end{array}$ \\
\hline Intercept & -0.091 & $2.016^{\star}$ & $0.578^{\star}$ & $0.591^{\star}$ \\
\hline Price Ratio $\left(\mathrm{P} / \mathrm{P}^{\star}\right)$ & $(-1.03)$ & $(16.79)$ & $(85.09)$ & $(2.27)$ \\
\hline México Price Index $(\mathrm{P})$ & $1.901^{\star}$ & & & \\
\hline & $(22.92)$ & & & \\
\hline USA Price Index $\left(\mathrm{P}^{\star}\right)$ & & $0.018^{\star}$ & & \\
\hline & & $(19.91)$ & & \\
\hline
\end{tabular}


Table 5 - OLS Regressions for the Peso/\$ Exchange Rate and Log(Peso/\$) Exchange Rate, 1886-1913

\begin{tabular}{l|c|c|c|c}
\hline $\log \left(\mathrm{P} / \mathrm{P}^{\star}\right)$ & & & $1.173^{\star}$ & \\
\hline & & & $(26.74)$ & \\
\hline $\log$ (México Price Index) & & & & $1.173^{\star}$ \\
\hline Log (USA Price Index) & & & & $(25.71)$ \\
\hline & & & & $-1.176^{\star}$ \\
\hline \# of Observations & 332 & 332 & 332 & $(-14.38)$ \\
\hline R2 & 0.614 & 0.580 & 0.684 & 0.684 \\
\hline Adj. R2 & 0.613 & 0.577 & 0.683 & 0.682 \\
\hline Durbin-Watson Statistic & 0.106 & 0.091 & 0.119 & 0.120 \\
\hline
\end{tabular}

T-statistics are in parentheses

* Significant at standard levels of significance

The regressions were done with and without logs. The dependent variable in all regressions is the exchange rate in pesos per dollar ${ }^{19}$. In the first regression, the peso-per-dollar rate is regressed on the ratio between the Mexican and US price indexes. For this period, the regression coefficient of the price ratio is 1.901, significant at standard levels of significance ${ }^{20}$. This coefficient implies that the exchange rate is directly and positively associated with the price ratio of the two countries. When the exchange rate is regressed on the individual price indexes of the two countries, both coefficients have the correct signs and are significant at standard levels. Mexico's price-index coefficient is positive, signifying that it directly affects the peso-per-dollar exchange rate, and the coefficient sign of the US price index is negative, supporting the theory that an increase in the price level in the United States would have a negative influence on the peso-per-dollar exchange rate.

19 This dependent variable is not to be confused with the variable graphed in Figure 1 , dollars per peso, the exact inverse of the variable used in the regressions.

20 As Froot and Rogoff (1995) demonstrate, the fact that this coefficient is not equal to 1 does not necessarily disprove the existence of PPP. 
When both of these regressions are done in log form, the results do not vary much from the previous regressions, although the coefficients for the individual price indexes of Mexico and the United States do become bigger in absolute value.

For the four regressions reported here, the Durbin-Watson statistics are quite low, indicating evidence of positive autocorrelation in the residuals. The estimators are unbiased, but they might be overstating the relationship that exists between the dependent and the independent variables. Computing the same regressions utilizing the first differences of all variables, computing a first-order autoregressive model (AR(1)) and/or including a time trend does not solve the problem of autocorrelation: the Durbin-Watson statistics do become a bit bigger but the t-statistics are meaningless; furthermore, some coefficients show the wrong signs. The regression results obtained when using the first differences of all the variables reflect the fact that the relation between the exchange rate and the price indexes is long-term in nature. That is, the economic association between the exchange rate and the price indexes is lost when using first differences: the $\mathrm{R}^{2}$ was almost zero with first differences in all regressions; the adjusted $\mathrm{R}^{2}$ was also near zero and in some cases, it was negative.

In order to overcome some of the limitations of the results obtained via OLS and to complement the general tendencies observed in Table 5, Cointegration Analysis ${ }^{21}$ is carried out to confirm the existence of purchasing power parity between Mexico and United States for the period of interest.The results obtained with this technique are presented in Table 6, along with Vector Error Correction estimates.

21 In their 2000 article, Gomez-Galvarriato, A., and Musacchio, A., carry out a cointegration exercise between the exchange rate Peso $/ \$$ and three different Mexican price indexes constructed by them. One of these indexes is utilized here. The period they analyzed runs from 1888-1904. The difference and added contribution of this work lies in analyzing a longer period of time - including the time after 1905 when a de facto, fixed exchange rate prevailed between the two countries - and in establishing a long-run equilibrium relationship (PPP relationship) between the exchange rate and the price ratio of the Mexican and US price indexes, which is proven to exist before and after 1905. 
Table 6 - Johansen Cointegration Tests and VEC Estimates, 1886-1913

\begin{tabular}{l|l|l}
\hline Sample(adjusted): 1886:06 1913:10 & & \\
\hline $\begin{array}{l}\text { Included observations: } 329 \text { after adjusting } \\
\text { endpoints }\end{array}$ & & \\
\hline Trend assumption: Quadratic deterministic trend & & \\
\hline Series (in logs) $1:$ Peso per Dollar, Price Ratio México/US & \\
\hline Lags interval (in first differences): 1 to 2 & & \\
\hline
\end{tabular}

\begin{tabular}{|c|c|c|c|c|}
\hline \multicolumn{5}{|c|}{ UnRestricted Cointegration Rank Test } \\
\hline Hypothesized & & Trace & 5 Percent & 1 Percent \\
\hline No. of CE(s) & Eigenvalue & Statistic & Critical Value & Critical Value \\
\hline None * & 0.05 & 18.19 & 18.17 & 23.46 \\
\hline At most 1 & 0.01 & 1.66 & 3.74 & 6.40 \\
\hline
\end{tabular}

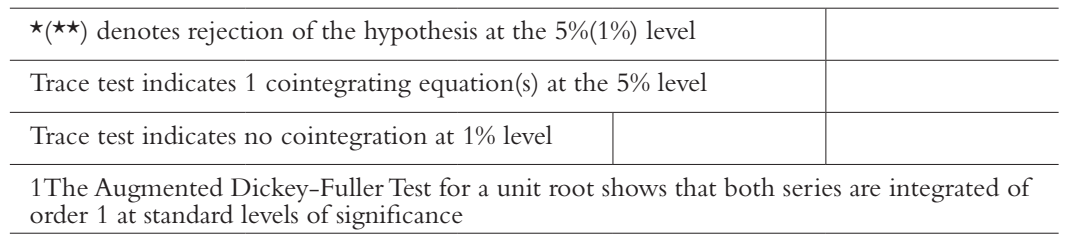

Vector Error Correction Estimates

\begin{tabular}{l|l|c|c|c}
\hline \multicolumn{2}{l|}{ Cointegration Equation } & $\begin{array}{c}\text { Peso per } \\
\text { Dollar }\end{array}$ & 1.00 & \\
\hline Standard errors in () & & $\begin{array}{c}\text { Price } \\
\text { Ratio } \\
\text { Mex/US }\end{array}$ & -1.78 & \\
\hline t-statistics in [] & & & $(0.25)$ & \\
\hline & & & $-7.04]$ & \\
\hline & & Constant & -0.61 & \\
\hline
\end{tabular}


The Trace Test indicates the existence of a cointegration equation ${ }^{22}$ at the $5 \%$ level of significance between the exchange rate Peso per Dollar and the price ratio of the Mexican and US price indexes, both in $\log$ form. The Vector Error Correction estimates ${ }^{23}$ show that there is a long-run equilibrium relationship between the exchange rate Peso/\$ and the price ratio of Mexico and the US, confirming the existence of PPP between these two nations over the period of interest.

Further confirmation of the results obtained through OLS and Cointegration Analysis is obtained when the exchange rate peso-perdollar is graphed with the price ratio between Mexico and the United States. Figure 3 shows this relationship.

Figure 3 - Exchange Rate and Price Ratio Mexico/US, 1886-1913

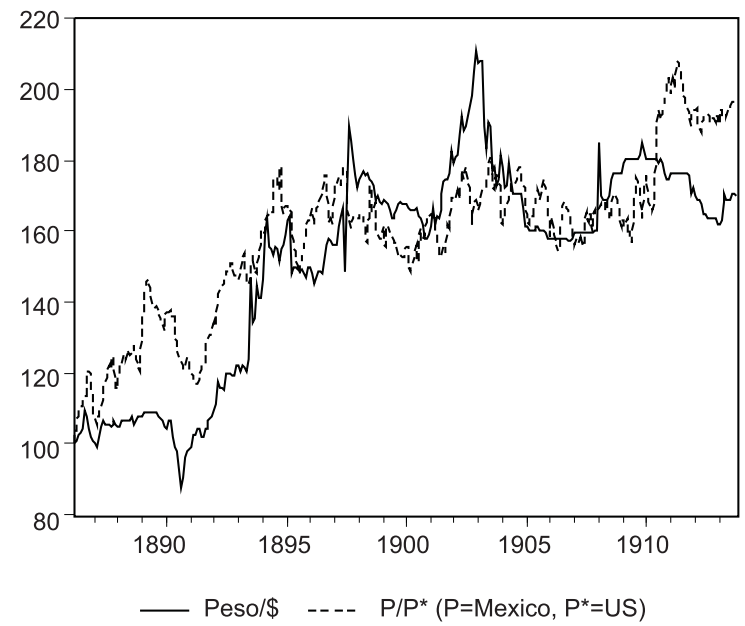

When the indexed peso-per-dollar exchange rate and the indexed price ratio between the price indexes of Mexico and the United States are compared in the same graph, the relation between these two variables

22 A quadratic, deterministic trend was chosen to test cointegration between the variables as they seem to follow a path - exemplified in Figure 3 - consistent with this behavior. In spite of this, a cointegration equation was also found with a linear, deterministic trend.

23 The constant included in the VEC estimates captures market distortions created by trade barriers that were already in use during those years. Kuntz (2007) describes in detail the Mexican industrial policy of the period. 
is evident. When the same graph is done with the exchange rate and the price ratio not indexed to March 1886, the basic figure of the graph does not change. A positive relationship between the two variables is still highly visible, confirming that the results presented here offer evidence in favor of the PPP doctrine as it is applied to these countries for the period of time under study.

Figure 3, along with the results shown in Tables 5 and 6, are provided as evidence in support of the existence of purchasing power parity between Mexico and the United States, at least for the period 1886-1913.

\section{Conclusions}

The price of silver fell from around 60 pence per ounce 0.925 fine in 1870 to a low of about 24 pence in 1902, the lowest value silver reached during the period of interest, 1870 to around 1910. As a result of this depreciation, the Mexican peso depreciated while it was on the silver standard. The exchange rate in dollars per peso fell from a high of 0.919 in 1877 to a new level of around 0.488 in the early 1900s. In 1905, when Mexico left the silver standard, this rate had stabilized at 0.500 dollar per peso; this rate, at least until 1910 , never deviated much from this new level. The peso did attain a brief period of rising value in 1890, when the Sherman Act was enacted in the United States, but this appreciation did not last long, and by 1891 it was depreciating again.

The depreciation of the peso deepened the already closed economic association with the United States. It generated an export boom that was mainly directed to the US, and it allowed Mexico to begin its greatest period of industrialization with inputs and technical assistance from the US. Even though Mexican exports reached record levels while its currency was depreciating the most, it is also true that this depreciation translated into higher internal prices in Mexico.

Purchasing power calculations for Mexico and the United States offered strong evidence that, at least for the period March 1886 October 1913, support the theory of purchasing-power parity (PPP). The exchange rate peso per dollar was regressed on the price ratio of 
the individual price indexes of both countries. The same regressions were also done in $\log$ form. Consistently, all parameters showed the correct signs and were significant at standard levels of confidence. Cointegration analysis confirmed these results, showing the presence of a long-term relationship between the exchange rate and the price ratio of both countries. This relationship was also significant at standard levels of confidence.Vector Error Correction estimates offered evidence that there is indeed a long-run equilibrium relation between the exchange rate Peso/\$ and the price ratio of Mexico and the US. Finally, the exchange rate and the price ratio were graphed together. The graphical representation shows that the exchange rate and the price ratio followed each other very closely, further demonstrating that PPP seemed to hold for the period under consideration.

The existence of PPP for the period analyzed confirms the very close association that has existed between Mexico and the United States for so long, relationship that seems to have deepened during the period analyzed, when the Mexican currency depreciated in step with the silver metal. The formal testing for the existence of PPP between these two countries captures the close ties that have united these nations for well over a century.

\section{References}

BEATTY, Edward.The Impact of Foreign Trade on the Mexican Economy: Terms of Trade and the Rise of Industry 1880-1923. Journal of Latin American Studies, 32: 399-433, 2000.

BOJANIC, Antonio. Evidence of Purchasing Power Parity in Silver-Backed Mexico and India. The Australian Economic History Review, 50:3, pp. 306-320, 2010.

BORDO, Michael; MEISSNER, Christopher and WEIDENMIER, Marc. Currency Mismatches, Default Risk, and Exchange Rate Depreciation: Evidence from the End of Bimetallism. World Economy \& Finance Research Programme Working Paper No. WEF 0010. Available at SSRN: <http://ssrn.com/abstract=941178>, 2006.

CATAO, Luis. Mexico and Export-led Growth: the Porfirian Period Revisited. Cambridge Journal of Economics, 22 (1): 59-78, 1998.

COELLO, Ermilo; CALDERON, Luis; NAVA, Oteo; ROSENZWEIG, Fernando; COSSIO, Daniel and PERALTA, Gloria. Historia Moderna de Mexico, México, Editorial Hermes. El Colegio de México (1960). Estadísticas Económicas del Porfiriato. 1. Comercio Exterior de México, 1877-1911, México, El Colegio de México, 1965. 
FLANDREAU, Marc The Glitter of Gold: France, Bimetallism, and the Emergence of the International Gold Standard, 1848-1873. Oxford: Oxford University Press, 2004.

FLYNN, Dennis and GIRALDEZ, Arturo. Cycles of Silver: Global Economic Unity through the Mid-Eighteenth Century. Journal of World History, 13(2):391-427, 2002.

FRIEDMAN, Milton. Bimetallism Revisited. The Journal of Economic Perspectives, 4: 85104, 1990.

. Franklin D. Roosevelt, Silver and China. Journal of Political Economy, 100: 62-83, 1992.

FROOT, Kenneth and ROGOFF, Kenneth. Perspectives on PPP and Long-Run Real Exchange Rates. In: GROSSMAN, G. and ROGOFF, K. (eds). Handbook of International Economics. Amsterdam: North Holland, p. 1647-1688, 1995.

GOMEZ-GALVARRIATO, Aurora.The Evolution of Prices and Wages in Mexico from the Porfiriato to the Revolution, Coatsworth \& Taylor (eds.). Latin America and the World Economy Since 1800, Cambridge, Mass., Harvard University Press, pp. 347-378, 1999.

GOMEZ-GALVARRIATO, Aurora and MUSACCHIO, Aldo. Un Nuevo Indice de Precios para México, 1886-1929 [A New Price Index for México, 1886-1929]. El Trimestre Economico, 1: 47-91, 2000.

HABER, Stephen Industry and Underdevelopment: The Industrialization of Mexico, 18901940. Stanford University Press, 1995.

KEMMERER, Walter. Inflation and Revolution: Mexico's Experience of 1912-1917. Princeton University Press, 1940.

KUNTZ, Sandra. La Redistribucion de los Cauces del Comercio Exterior Mexicano: Una Vision Desde la Frontera. Revista Frontera Norte, 13:24, pp. 111-157, 2000.

. Nuevas Series del Comercio Exterior de Mexico, 1870-1929. Journal of Iberian and Latin American Economic History, 20:2, pp. 213-270, 2002.

El Comercio Exterior de México en la Era del Capitalismo Liberal, 1870-1929. México, El Colegio de México, 2007.

Las Exportaciones Mexicanas Durante la Primera Globalización (1870-1929). México, El Colegio de México, 2010.

LEAVENS, Dickson. Silver Money. Bloomington, Indiana: Principia Press, Inc., 1939.

LUDLOW, Leonor and MARICHAL, Carlos, eds. Banca y Poder en México, 18001925. Méjico: Grijalbo, 1986.

MÁRQUEZ, Graciela. Protección y Cambio Institucional: La Política Arancelaria del Porfiriato a la Gran Depresión. Centro de Estudios Económicos, El Colegio de México, Serie Documentos de Trabajo No. 5, pp. 1-27, 2001.

MAURER, Noel. The Power and the Money: The Mexican Financial System, 18761932. Palo Alto, CA: Stanford University Press, 2002.

MITCHELL, Brian, R. Editor. International Historical Statistics:The Americas, 1750-1988. New York: Stockton Press, 1992.

MORRIS, William, Editor. American Heritage Dictionary of the English Language. New York: American Heritage Publishing Company, Inc., \& Houghton Mifflin Company, 1969. 
MUSACCHIO, Aldo. The Monetary Reform of 1905: A Study of the International Conditions that Led to the Adoption of the Gold Standard in Mexico. Revista Secuencia, 52, pp. 64-98, 2002.

MUSACCHIO, Aldo; GOMEZ-GALVARRIATO, Aurora and PARRAL, Rodrigo. Political Instability and Untimely Dissolution: Partnerships, Corporations, and the Mexican Revolution, 1910-1929. Harvard Business School Working Paper No. 08-092, 2008.

NBER Series 14105. National Bureau of Economic Research. Macro History Database, Washington.

PASSANANTI,Thomas. Nada de Papeluchos! Managing Globalization in Early Porfirian Mexico. Latin American Research Review, 42:3, pp. 101-128, 2007.

PIATT,Andrew. The End of the Mexican Dollar. Quarterly Journal of Economics, 18: 321356, 1904.

REDISH,Angela. Recent Contributions to the History of Monetary and International Financial Systems: A Review Essay. European Review of Economic History, Cambridge University Press, Vol. 10(02), pp. 231-248, 2006.

RIGUZZI, Paolo. From Globalisation to Revolution? The Porfirian Political Economy: An Essay on Issues and Interpretations. Journal of Latin American Studies, 41, pp. 347-368, 2009.

ROGOFF, Kenneth. The Purchasing Power Parity Puzzle. Journal of Economic Literature, 34(2): 647-668, 1996.

ROSENZWEIG, Fernando, H. El Desarrollo Económico de México, 1800-1910, [Economic

Development of México, 1800-1910]. Toluca, México: El Colegio Mexiquense, A.C., 1989.

ROYAL COMMISSION ON INDIAN CURRENCY and FINANCE, (cited as Hilton Young Commission), Vol. I, Report of the Royal Commission on Indian Currency and Finance (Cmd. 2687), 1926.

SCHELL, William. Money as Commodity: Mexico's Conversion to Gold Standard, 1905. Mexican Studies/Estudios Mexicanos, 12: 67-89, 1996.

Silver Symbiosis: Reorienting Mexican Economic History. Hispanic American Historical Review, 81(1): 89-133, 2001.

SCHETtinO, Macario. Cien Años de Confusión. México en el Siglo XX. México: Taurus, 2007.

VELDE, Francois and WEBER, Warren. A Model of Bimetallism. The Journal of Political Economy, 108(6): 1210-1234, 2000.

VILlEGAS, Daniel C. Moneda y Bancos. Historia Moderna de México, [Money and Banking, Modern History of México]. México City, 1955.

WARREN, George and PEARSON, Frank. Prices. New Jersey:The Haddon Craftsmen, 1933.

WILliAMSON, Jeffrey and GÓMEZ-GALVARRIATO, Aurora. Was it Prices, Productivity or Policy? The Timing and Pace of Latin American Industrialization After 1870. National Bureau of Economic Research, Working Paper 13990, 2008. 